\title{
The Independence of Albania
}

\author{
Ph.D. Sokol Pacukaj
}

Aleksander Moisiu University

\section{Doi:10.5901/mjss.2013.v4n11p763}

\section{Abstract.}

The purpose of this article is to analyze the steps that led to the Albanian independence in the early '900. Albania was a state under the rule of the Ottoman Empire and benefited from the protection of its Vilayets (regions) on the part of the empire. With the weakening of the Ottomans, Albanians were looking for a solution to their future and the only one who could save the last stronghold of the Ottomans was their independence from the empire. The methodology of this article is based on an exploration of archival sources and on the basis of an assessment of historical texts which deal with the question of the Independence of Albania.

Keywords: Independence, Vilayet, Ottoman empire, Albania.

\section{Albanian territorial organisation under the empire}

While the Ottoman power waned, some authentic feudal principalities formed the so called Large "Pashallik". Istanbul had placed in each district its sipahis: soldiers who had to respond to the call of the sultan and show up on horseback, accompanied by a number of infantry. To meet the expenses, the sipahis enjoyed a timar, which were plots of land taken from public lands. It was based on income and not on the extension. It was thought that the timar should make its holder a certain amount. Their number varied greatly depending on the policy of the sultans. They were almost completely in the lowlands and highlands. Theoretically, the sipahis had to go to collect the tithe from his peasants, but also they were getting the fees for the Sultan. It instituted a kind of feudalism, albeit limited by the power of the sultan who could always intervene in the allocation of timar.

The various sipahis were part of the districts in which the territory was divided. The districts were the Sanjaks, named to mean feudal and military districts.

The Sangiak Bey was the chief of sipahis of a given part of the country.

Especially in the northern mountainous areas, some regions were exempt from the timar regime and had the right to administer according to the ancient customs. They only had to pay a fee as a sign of submission. These geographic areas were populated by tribes, led by the head of a large family: Bayraktar, hereditary office, which applied the traditional law based on besa, the word of honor.

Following the conversion to Islam, many Albanians reached the upper echelons of the empire: the Great Vizir, which were governors of provinces, many generals, used in all orders of justice and finance. The crisis of the Ottoman state reflected the transformation of timar. They formed the major territories, private property, sipahis, taking advantage of the weakness of the central authority had formed bringing together more timar or taking possession of the lands of the sultan or religious institutions.

Thus a landed aristocracy, from the military class was born. The weakening of the power of Istanbul, later, pushed sipahis to neglect their military service obligations. Similarly, the owners of the new wide areas did not deposit the taxes to the treasury which prevailed on the peasants, thus becoming powerful feudal lords of the region. These powers were slowly made hereditary to the ones who, in Albanian history, are called the "Big Pashalik". One, for example, was in Shkodra. Another one was formed in the environs of the region of Tepelenë.

On the basis of the Napoleonic wars throughout southern Albania, Epirus and Thessaly were incorporated in a Pashalik which included the Albanian and Greek, with 934 villages. After a series of battles, the Sultan was able to recover his territories. The "Big Pashalik" disappeared in 1831. Albania was divided into vilayets.

Vilayet $=$ provinces of European Turkey (around 6). Among these were three Albanian vilayets:

1. Shkoder, Albanian equivalent north-central;

2. Janina, which included southern Albania and Epirus; 
3. Kosovo (Kosova) which did not coincide with the Yugoslav and Kosovo today. Its capital was Skopje. It extended to Macedonia of Vardar and included:

- The Sanjak of Novi Pazar: Slavic Muslim majority population (comparable to the Bosnian Muslims, serbofones)

- Kosovo itself, with the majority Albanian (Muslim mostly and a small part Catholic) and the minority Serbs (Orthodox) and with a presence of Muslim Slavs in the South of Prizren (the Gorani)

- The territory of Skopje, where there lived Macedonian Slavs, Albanians, Serbs, Gorani, Turkish communities, Greek and Roma.

In these provinces, the population was multi-ethnic, with the presence of Albanians, Montenegreans, Serbs, Greeks, Macedonians and Turks. When the official end of the military feudal system in the countries of Albania happened, it was introduced as the civil administration of the Ottoman state.

This system, in Albania, strengthened the largest private property, while the heads of the hill tribes were ready to defend their privileges by force.

Everywhere armed revolts broke out, supported by the hostile peasants to pay taxes to the state and to submit to military service, such as in Gjirokastra, Berat and throughout southern Albania.

\section{The birth of albanian nationalism}

The special conditions in which the Albanians were incorporated into the Ottoman government team had delayed the emergence of a national consciousness that balance out the internal contrasts, especially since the vast majority of the population was Muslim and made it possible to identify with the imperial Ottoman idea.

Within this climate the first bearers of the modern national idea appeared as a result of impulses from abroad.

The first attempts were concentrated in the action of opening of non-denominational schools. In these ones it was taught in Arabic, Greek and Italian. With the emergence of national targets, an attempt was made to open schools where teaching was instructed in Albanian, with a new alphabet and simplified textbooks.

During the great Balkan crisis of 1875-1878 the issue of Albanian schools was at the center of the intellectuals debates, which faced the hostility not only of the Ottomans, but also of the Patriarchate of Constantinople. The Ottomans continued to open public schools in Turkish, while the Greek Patriarchate multiplied educational institutions in the south of the country. In 1878, in the three Sanjaks of Gjirokastra, Berat and Vlora there were 80 Turkish schools, 163 Greek schools, but not any Albanian school. The native language was used only in the Catholic schools of Shkodra, where it was given instruction in Italian, but with the Albanian as a second alternative.

All this produced a new attitude among the Albanian leadership. It began to grow a strong concern for the advances of the Greek and Serbian claims on Albanian vilayets albeit their Albanian majority of population.

The Albanian national body had internal divisions of a religious nature:

- Muslim majority (70\%)

- Catholics in the area of Shkodra

- Greek-Orthodox in the area of Janina (over 20\%)

and linguistic diversity:

- Gheg in the northern areas

- Tuscan in the central and southern regions.

With the Treaty of Saint Stefan, Russia included some Albanian regions within the Bulgarian border. Faced with such a situation, the Albanian deputy in the Ottoman parliament of Janina, Abdul Frashëri, coming from a Bey family in the south, as the interpreter of national bodies that were synthesized in the memorandum in which it called for the administrative autonomy of the Albanian villages gathered in a single province. The request was not taken into consideration. There were attempts at direct approach to Greece for political and military alliance function in antiOttoman. The attempt fell through however, because Greece refused to recognize the ethnic borders of an independent Albanian state. With the Treaty of Saint Stefan, the main issue was, in fact, the need to reject the expansionist ambitions of the Balkan neighbors, Montenegreans, Serbs, Bulgarians and Greeks, thesis to the partition of Albanian lands. Three days before the Congress of Berlin, June 10,1878, in Prizren opened the meeting with the delegates of the Albanian Vilayets. On this occasion, under the leadership of Abdul Frashëri, the Prizren League for the Protection of the rights of the Albanian nation was procreated. 
The league decided to form an armed force capable of protecting Albanian regions which were threatened from neighboring states with the annexation of Albanian regions. This League also addressed a note of protest to the Congress of Berlin.

From the political demands' point of view, however, this was in the presence of a division among the Albanians of perspective on what was supposed to represent the League:

1. Some, especially the large landowners, aspired to bring together in a single Muslim organization in all the representatives of all the peoples of the Balkans, to preserve the integrity of the empire;

2. The most radical nationalists, the "Albanian patriots", however, that the league wanted to remain Albanian organization, bringing together the faithful of the three religions and that his goal was the autonomy of the Albanian villages within the empire .

For everyone, of course, at that time, the best solution seemed, however, to remain under Ottoman rule.

The Congress of Berlin, which opened on June 13, 1878, drastically reduced the territories for Bulgaria. Even the request of the Serbian Pristina went ignored, with some minor territorial allocations. Montenegro occupied the cities that had been assigned to Podgorica and Antivari. Greece claimed Epirus and Thessaly. As for the Albanian requests, none of the Great Powers representatives raised the issue. The Albanians reacted to the military occupation of Montenegro. Since 1879 began an armed struggle.The league, clarified its program, defining the formal request for autonomy as a central demand of the movement. The request to this point in materialized search for autonomy under Ottoman suzerainty and the unification of all Albanian regions in a single Vilayet. It was called the Albanian territory, between the Vilayet of Shkodra, Kosovo, Monastir and Janina.

Prince Nicholas of Montenegro did not hesitate to advance his troops to occupy the promised territories, Podgorica and Antivari. He was twice defeated by irregular Albanian volunteers of the League. Faced with the risk of seeing explode the issue at the international level, the Ottoman authorities found themselves forced to send their troops to break the Albanian resistance.

The disastrous outcome of the resistance caused, in 1880, an open rupture in the League, during its meeting in Dibra, between the old Ottoman and the team pro-radical component. This was not even more alien by a detachment from the empire, so that an egg elected governing body that proclaimed itself the "Provisional Government" Albania. The Albanian administration was settled in Prizren and Gjakova where it was formed an army.

The Ottoman authorities reacted and began to rally the Beys. In 1881, the hard work of the Ottoman forces poses a provisional end to the alarming threat of the Albanian independence. Prizren was taken after fierce resistance of irregular Albanians. The league was dissolved, its leaders were sentenced to long prison terms, and the same Frashëri was sentenced to death, although pardoned later.

Despite the end of the League, the representatives of a national awakening movement were activated from the own capital of the empire. At that time it arose a series of national-patriotic associations, where merchants and artisans collaborated for success, as well as representatives of the still small bourgeois intellectual class, they all spread the idea of a common Albanian state beyond all religious and social boundaries by proliferating the cause and spread of the Albanian language in the territories populated by Albanians and centers of emigration out of the motherland: especially in Romania, in southern Italy, Bulgaria, Egypt, and, as has been said, in the same Istanbul (which they call Stamboul), in the United States.

In 1887 the first public national school was opened in Korca, where the teaching was in Albanian and both Muslim and Christian students were welcomed. It was a victory, limited but undeniable for the Albanian nationalism. So a national sentiment spread among the lower strata of the population. However, as mentioned above, the most active centers of Albanian nationalism remained abroad.

\section{The "Rilindja" and birth of the albanian question}

The Albanian question rose up at the European level on the occasion of the affirmation of the Macedonian question. The borders of this province were not easy to define, and included a number of territories inhabited by Albanians. In 1898 the ALLOY of Peje (PEĆ) was born, which manifested two trends:

Conservatives claimed:

- A unique Vilayet formed from those of Shkodra, Kosovo, Janina and Thessaloniki

- Educational reforms such as the introduction of Albanian next to Turkish language which still remained the language of the administration;

the Liberals demanded: 
- They limited up to 3 vilayets to be unified, with the exception of that in Thessaloniki

- Albanian as the language of administration.

Two requests were sent to Istanbul which remained unanswered. In support of the thesis of the liberals, Sami Frashëri (brother of Abdul) published his work: "Albania, what it was, what it is and what it will be", in 1899. The manifesto of the period referred to as the Albanian renaissance, the so-called "Rilindja". The Albanian people were presented as "the oldest nation" in Europe given its descent from the Pelasgians, and serve as a unit of language and blood. In the same story of the family of Sami Frashëri, formed in the Islamic world, with a prominent place in Turkish literature, reflects the fate of the families of Albanian Beys, whose members, through a painful process of growing disillusionment, reneged loyalty to the sultan and devoted themselves to national objectives. National ideas, however, had not the support of the population. The public road continued to be dominated by the Beys and Bayraktars.

Istanbul, however, continued its policy of repression and in 1902 decided the closure of the school of Korca, as a request of patriarchy.

The climate of terrorism, which started after the uprising in Macedonia dell'llinden, there present even in the Albanian regions, triggered especially by gangs of Greeks (andartes = rebels) which also led to some sensational killings of intellectuals and representatives of Albanian nationalists.

The Albanian answer was the foundation of "Liberation Committee of Albania" in Monastir, which organized similar committees in many Albanian cities and settled the first ÇETA (guerrilla units) which formed its departments throughout the south of the country.

Thus began to develop an activity of a revolutionary type. The first act was manifested by the assassination of the Greek Metropolitan of Korça, Foti, one of the leaders of the Greek communities of the region (1906).

\section{The years of the great riots: $1910-1911$}

The revolution of the Young Turks, in 1908, was greeted favorably by Albanian nationalists, especially because they promised to replace the absolute power of the Sultan with a constitutional regime based on equality of all nationalities of the empire. It was also granted the request to restore the constitution of 1876 and this developed a remarkable series of patriotic circles, while they began to print newspapers in Albanian. It was in November 1908, which was adopted the Latin alphabet with some diacritical scripts, which is still in use today. The centralizing tendencies and the new Ottomanisation of the Young Turks, which manifested itself, for example, the obligation to restore the Arabic alphabet for the Albanians, put at peril the Albanian provincial autonomy.

From 1909 on, internal disturbances occurred within the Albanian territory, uprisings and wars between gangs followed without respite.

In 1910 The Vilayet of Kosovo, saw a vast movement of anti-Turkish Albanians, whose clan turned into small armies. The armed revolt began in Pristina and quickly spread to the entire vilayet. So the insurrection spread throughout the vilayet of Shkodra. The rebellion was against the neo-Ottoman modernization, against new taxes, against compulsory military service, against the census, against the Turkish language and the Arabic alphabet. The rebellion was put down with a massive deployment of troops. Many people took refuge in Montenegro, whose king, Nicola, provided weapons to the insurgents, and who had alliance agreements with the leaders of the clans, especially with the Catholic Mirdita region, in anticipation of an eventual enlargement of Montenegro on the areas of Shkodra.

In March 1911 riots returned, this time in northern Albania. However, the coordination with the Kosovo Albanian leaders and the Tuscans was absent. The Young Turks tried to conciliate the uprising promising the re-opening of Albanian schools and the use of the Latin script. But the truce did not last long. In Kosovo resulted in open confrontation between the militias of local potentates Albanians and Serb communities, now aligned with Belgrade and supported by the Chetniks, the irregular militias in the region. The Albanian guerrilla shooting in October of 1911 coincided with the Italian invasion of Libya.

It declined in the early 1912, when the Ottoman parliament was dissolved and new elections were called. The reconfirmation of the overwhelming majority of the Young Turks encouraged them not to change their deeply nationalistic attitude. This rekindled more vigorously the insurgency in Kosovo (May 1912). Now the Turkish nationalism was facing the Albanian one.

Even the Christian states were alarmed:

- Sofia and Belgrade in 1912 signed two treaties with which it was recognized to Serbia the right to annex the whole region of Kosovo and a part of the territories to the north, as well as the division of the territories of the southern regions of Albania. 
- Greece and Bulgaria concluded another treaty which involved the division of the southern Albanian regions (May 1912) The Albanian leaders several times presented requirements to achieve autonomy in administrative and institutional Albanian Vilayet. In the absence of a prompt response in Istanbul, they occupied the cities of Prizren, Skopje and Novi Pazar. In all, in the Vilayet of Kosovo, there were about 45,000 armed Albanians. The Ottoman administration was completely paralyzed. Before that confrontation, the Ottoman authorities were forced to enter into negotiations and to accept the main Albanian requests, thereby allowing autonomy in all the four Vilayets of Janina, Kosovo, Monastir and Shkodra (4 September 1912). It was the victory of the Albanians. From the Vilayets now emerged a real Albania for the first time.

\section{The First Balkan War for Albania}

King Nicholas of Montenegro took the indication of what was happening in Albania to declare war on Turkey in October of 1912, followed by the states of the Balkan League. The progress of the war was favorable to the Allies. The Turks had to offer to Bulgaria truce negotiations.

The Albanian committees took advantage of this power vacuum that was created with the Turkish defeat. Since November 1912 the Albanian political leaders in exile in Romania, above all Qemal Ismail, had turned to seek support from the Great Powers.

The support came mainly by Austria-Hungary and Italy. These two powers saw the usefulness of an autonomous Albanian context in the Ottoman Empire or it might serve a guaranty in the balance of the Balkans, especially in the antiRussian part, Vienna, or as an access bridge to the region, and to exclude for Rome the influence of Greece in Vlora surroundings. Vienna and Rome moved concretely. They sent experts in the Western Albanian Vilayets to identify and trace the boundaries of the ethnic Albanian lands.

The situation on the ground had evolved. The Albanian territory had become deployment zone of the armies of Serbia, Montenegro and Greece who had already occupied some Albanian regions.

Ismail Qemal, who returned from the trip to European capitals, summoned on 28 November, in Vlora, the National Congress, which proclaimed Albania "an independent and sovereign state". It was formed at that time a provisional government to which Ismail Qemal became the prime minister and also the foreign minister, as deputy he chose the Catholic priest Dom Nikollë Kaçorri. Muslims and Christians faced with the task of ensuring the survival of the Albanian nation-state in a hostile environment, while in fact the Serbian, Montenegrean and Greek armies moved to Shkodra and Vlora. This event is considered as the foundation of the Albanian state and November 28th is their national day.

In fact, the event went unnoticed: the government of Ismail Qemal reported the decision of independence to the Western powers, Turkey and the Balkan states, asking them to recognize the Albanian state and its government. The government was unsuccessful at this point.

The external troops continued their advances to occupy the areas referred to in their alliance agreements. Serbia occupied Tirana and Durres, Greece occupied Epirus, the two towns of Shkodra and Janina were under the siege of Montenegro. The position of Vlora government became increasingly unsteady; meanwhile Istanbul was giving orders to his army in retreat to dissolve the Assembly of Vlora and to arrest Ismail Qemal.

The division of the Albanian territory was avoided thanks to the objections of Asutria-Hungary and Italy. The matter was in the hands of the Conference of Ambassadors in December 1912. The conference was in front of an official declaration of the Albanian national will, thus it decided that, contrary to the decision of Vlora, Albania was not to be an independent state, but "an autonomous state under the sovereign of the Sultan and under the assurance and control of the six Great Powers".

At that point it came to define the boundaries of an Albanian national space, which involved the question of access to the sea of Serbia and Serbian application in the area. The confrontation between Vienna, its vision of Albania, and Serbia together with Montenegro, assisted by Russia, became the diplomatic showdown between the Triple Alliance and the Triple intent. At the European registries became a fact that there might be an autonomous or independent Albania, to this fact Serbia itself did not oppose. Vienna refused to accept what was instead a Serbian port on the Adriatic. Against the Serbian presence on the eastern Adriatic coast Italy sided as well. Vienna had its support from Berlin and Rome. The Austrian answer was clear in all terms that the Empire would not tolerate a Serbian maritime outlet in the Albanian national territory, invoking, paradoxically (given the situation within the Dual Monarchy) the right of the Albanians to be a nation. Belgrade claimed that the Albanian autonomy would be accepted in exchange to a Serbian port in the Adriatic. St. Petersburg, fearing war, gave way in front of the Austrian firm attitude. The Serbian aspirations were overshadowed. It 
was thus established a joint Albanian - Montenegrean border and then was given the outlet to the sea for Serbia. Reactions in Belgrade were of great bitterness, because it was implied the withdrawal of troops from Albania.

The boundaries proposed by Vienna also included practically the whole of Kosovo, even Dibra and Ohrid in Macedonia and also Janina. This time neither Serbia nor Russia stepped back. The King Nicholas of Montenegro declared himself ready to succumb just to have Shkodra. These duels lasted all winter 1912-1913. The Montenegrin troops, meanwhile, with the support of Serbia, had taken Shkodra, despite the fierce defense put up by a big landowner in the region, Toptani Esad Pasha, who did not hide the ambition to be part of the vertices of the emerging Albanian state. It was necessary the intervention of Austria and the arrival of an international fleet to force the evacuation of King Nikola and put the city under international administration.

The authority of the Albanian government was limited to the triangle Vlora - Berat - Lushnjë; Toptani, controlling the region of Durres - Tirana, giving rise to a counter. The peace tract of London, signed in May 30, 1913, effectively left the Albanian affair unclosed.

\section{Ratification of independence: July 29,1913}

In June 1913 the Serbian and Ottoman armies had evacuated the country, while only the Greeks continued to occupy the southern regions. At the same time broke the Second Balkan War, which ended July 30. The Peace Conference set up in Bucharest in that same 30th of July, with deeds that proceeded very rapidly, ending ten days later, on August 10, 1913.

Meanwhile, the Conference of Ambassadors in London, concluded its case on the Albanian question, when, on July 29, a new project was presented. It was confirmed the full independence of the Albanian state, but under the control of the six powers. It must be neutral and governed by a sovereign prince chosen by the powers. The control was planned for 10 years and would be carried out by an international committee of 7 members: 6 powers, plus an Albanian delegate, he would take care of the administration and the budget. It was also decided that the police would be submitted to the command of Swedish officers. The name of the king that emerged was that of Prince Wilhelm von Wied.

The act of 29 July created an Albania, but a partial Albania, since a substantially equal number of Albanians remained in the territories of Kosovo and Macedonia, given to Serbia, while the Greek Macedonia passed under the authority of Athens. With the Treaty of Bucharest, Macedonia was cut into two zones. Kosovo became Serbian: Belgrade had claimed it as "a holy land and the heart of the Serbian state". It became a very sensitive place for the Serbian nationalism. For the Serbs, the Albanians were nothing more than Turks, or just enemies, because they converted to Islam, and as soldiers they were loyal to the sultan. It began a policy of colonization of the region by distributing land to former combatants of the Balkan wars.

In the south-east was included the city of Korca (Koritza), occupied by the Greeks and inhabited by Greeks, and from there, the frontier was pointing towards the lake of Ohrid.

\section{The Prince of Wied, a kingdom for six months}

Within the borders drawn in London, Ismail Qemal tried to organize an administration, to increase the number of Albanian schools and to replace the old Ottoman laws with new legislation. But soon the clans showed their ambitions.

In October of 1913 he had formed a new independent government around Esad Toptani, in Durres. The powers were divided. Austria and Italy supported Ismail Qemal; Russia and France took a stand in favor of Esad Toptani.

Among neighboring states: Bulgaria and Romania maintained accurate relationships with the government of Vlora, Serbia instead, supported the government of Durres. Greece continued to claim southern Albania, which it called "Northern Epirus" and it sent irregular bands that fought the administration set up by Vlora. The Great Powers had agreed on William Wied, a Prussian officer, nephew of the Queen of Romania. Meanwhile Istanbul, according to its antiSerbian and anti-Greek function, promised to the government of Vlora, in case of a resumption of hostilities, would have succumbed Kosovo. Ismail Qemal signed a secret pact, to provide soldiers in Istanbul. A landing attempt was stopped by the European Commissioners. Ismail Qemal was forced to resign in 1914. He retired to Nice, where he died in 1919.

Esad Pasha Toptani was forced to do the same.

The Control Commission took the totality of power in Albania. The Greeks were encouraged to evacuate the south of the country, but during the retreat they organized Epirotes bands that imposed their authority using terror. They were gathered in a conference in the south city Gjirokastra, where they proclaimed the independence of the Northern Epirus and formed a government headed and controlled by a Greek. 
The Prince of Wied arrived in Albania, Durres, in March 7, 1914, on an Austrian ship, escorted by Italian, French and English units.

Not knowing absolutely the reality of the country the Prince surrounded himself with former officials of the sultan. Among these he chose the prime minister, while Toptani was appointed to the Ministry of the Interior and of that of War. These officials came into contact with the Greeks and negotiated with the government of Epirus in the north. On May 17, an agreement was signed in Corfu, which recognized to the southern territories a regime of semi-autonomy, with a local government and a police force, also the use of the two languages, Greek and Albanian. Senior officials should be appointed by the Albanian government in Durres. The agreement was not ratified because of the Albanian resistance. The Young Turks in Istanbul strongly criticized the government of Wied, and came to push the revolt of the peasants in the central regions of Albania. They wanted to launch a Muslim prince on the Albanian throne, thus on their side was Esad Pasha Toptani and the Mufti of Tirana.

In May, 1914, in the region of Tirana and Shijak, there were uprisings against the government of Durrës, thus Toptani was arrested, but by the Italian intermediation, was able to take refuge in Italy. The farmers continued to fight and in Shijak it was elected a General Council, with a president and a commander of the armed forces.

The government of Wied then ratified the Protocol of Corfu. The beginnings of World War I created a tragic situation in Albania. After the withdrawal of the International Commission of Control Albania found itself with:

- The authority of the Government of Wied limited to the ports of Durres and Vlora;

- Central Albania under the control of the rebels;

- The south of the country was dominated by Greek bands;

- The Dibra region occupied by the Serbian army

- The surrounding mountains in the hands of local leaders.

In August 1914 the opponents of Wied took possession of Vlora, while Austria, driven by war, abandoned his protégé, also cutting off the food, since it refused to take sides in the conflict.

On September 3, 1914 William of Wied embarked on a ship and went back to Germany, leaving Albania into chaos. Albania did not have the opportunity to establish itself as a state in 1912-1913. Strong men in Albania were those already established during the Ottoman system and the transition to the new order of the nation-state proved extremely difficult. To complicate matters, there were some Serbian officers, who bribed leaders in the north, and it was Greece who managed with its manipulation to bring out a filo-hellenic Epirus and a potentially separatist one, but, above all, to animate the long discord it was the struggle between the landowners for new or potential powers, as well as the differences in language, religion and political views, including local and regional interests.

\section{References}

C. Castellan, (2012), History of Albania and the Albanians, Argo

E. Hösch, (2005), History of the Balkan countries, Einaudi

G. Castellan,(1999), History of the Balkans, XIV-XX century, Argo

M. Vickers, (2009), The Albanians: A Modern History, Taurus 